\title{
T1 Vertebra
}

National Cancer Institute

\section{Source}

National Cancer Institute. T1 Vertebra. NCI Thesaurus. Code C33720.

The first thoracic vertebra counting from the top down. 